\title{
Glutathione peroxidase, superoxide dismutase and catalase activities in children with chronic hepatitis
}

\author{
Nagwa Abdallah Ismail ${ }^{1}$, Sawsan H. Okasha ${ }^{2}$, Anil Dhawan ${ }^{3}$, Azza M. O. Abdel Rahman', \\ Nehal Abdel Hamid ${ }^{1}$, Olfat Shaker ${ }^{4}$ \\ ${ }^{1}$ Pediatrics' Department, National Research Center, Cairo, Egypt \\ ${ }^{2}$ Pediatrics' Department, Cairo University, Cairo, Egypt \\ ${ }^{3}$ King's College Hospital, London, UK \\ ${ }^{4}$ Medical Biochemistry Department, Faculty of Medicine, Cairo University, Cairo, Egypt \\ Email: nagwa abdallah@yahoo.com
}

Received 16 August 2012; revised 23 September 2012; accepted 27 October 2012

\section{ABSTRACT}

The advantages of measuring hepatic oxidative status in liver biopsy are that it helps in diagnosis of hepatic dysfunction, reflects the degree of deterioration in the liver tissues, and helps to determine the severity of hepatic injury. We aimed to study the oxidative stress state in children with chronic hepatitis by using indirect approach in which antioxidant enzymes such as glutathione peroxidase (GPX), superoxide dismutase (SOD) and catalase (CAT) are determined in the liver tissue. The present study included 21 children and adolescents (12 males, 9 females) suffering from chronic hepatitis. Patients were selected from the Hepatology Clinic, New Children's Hospital, Cairo University from November 2006 till 2009 and compared with a group of 7 children who happened to have incidental normal liver biopsy. Children with chronic hepatitis had mean age $8.12 \pm 1.15$ years. It was further subdivided into 2 subgroups: chronic viral heaptitis $(n=13)$ and cryptogenic hepatitis $(n=8)$. GPX, SOD and CAT levels were measured in fresh liver tissue (cell free homogenates) using ELISA. In chronic hepatitis group; there was a significant increase in the hepatic GPX activity $(38.59 \pm 35.82 \mathrm{nmol} / \mathrm{min} / \mathrm{ml})$ as compared to the control group $(10.62 \pm 6.68$ $\mathrm{nmol} / \mathrm{min} / \mathrm{ml}$ ). Also a significant correlation was observed between SOD and both ALT $(r=0.87, p<0.05)$ and AST $(r=0.74, p<0.05)$. GPX correlated with ALT $(r=0.80, p<0.05)$ level in the chronic viral hepatitis subgroup. Our findings suggest that oxidative stress could play a role in the pathogenesis of chronic hepatitis. These preliminary results are encouraging to conduct more extensive clinical studies combining antioxidant therapy with various treatments.

Keywords: Glutathione Peroxidase; Superoxide Dismutase; Catalase; Chronic Hepatitis; Oxidative Stress

\section{INTRODUCTION}

The involvement of oxidative stress in the pathogenesis of hepatic dysfunction in human [1-5] has been investigated for many years. Some of the liver diseases were associated with an increase [6] or decrease [7-9] in antioxidant's contents. Usually hepatic antioxidants increase at the beginning of hepatic disease and decrease in severe hepatic injury. Oxidative stress results when reactive forms of oxygen are produced faster than they can be safely neutralized by antioxidant mechanisms and/or from a decrease in antioxidant defense, which may lead to damage of biological macromolecules and disruption of normal metabolism and physiology [5]. This condition can contribute and/or lead to the onset of health disorders and play a damaging role in a number of liver disorders [5].

Lipid peroxidation is implicated in the pathogenesis of several hepatic disorders in human [5-8]. Increased lipid peroxidation may be caused by inflammation related to viral infection and decreased antioxidant levels. The lipid peroxides formed may be chemotactic for the neutrophils causing increased inflammation, which further drives oxidant-mediated injury in the liver. Previous studies have demonstrated an increase in malondialdehyde (MDA) levels and decrease of the antioxidant capacity in acute and chronic hepatitis $[2,5]$.

Some of these studies were conducted using liver biopsy in human $[10,11]$. The advantages of measuring hepatic oxidative status in liver biopsy are that it helps in diagnosis of hepatic dysfunction, reflects the degree of deterioration in the liver tissues, and helps to determine the severity of hepatic injury, and, also, it aids in recommending antioxidant's therapy in patients that had a hepatic disease with derangement in hepatic antioxidant constituents. The main purpose of the current paper is to 
study the oxidative stress state in children with chronic hepatitis by using indirect approach in which antioxidant enzymes such as glutathione peroxidase (GPX), superoxide dismutase (SOD) and catalase (CAT) are determined in the liver tissue.

\section{MATERIALS AND METHODS}

\subsection{Study Population}

The present study included 21 children and adolescents suffering from chronic liver disease. Patients were newly diagnosed and selected from Hepatology Clinic, New Children's Hospital, Cairo University between November 2006 and 2009 and were compared with a group of seven children who happened to have incidental "normal" liver biopsy ( as a control group). The mean age of these patients was $8.12 \pm 1.15$ years. It was subdivided into 2 subgroups: Chronic viral hepatitis $(\mathrm{n}=13)$ and hepatitis of unknown etiology $(n=8)$. Informed consent was taken from the parents of children according to guidelines of the ethical committee of the National Research Center, Dokki, Egypt.

Inclusion criteria: Children suffering from chronic viral hepatitis or hepatitis of unknown etiology.

Exclusion criteria: Patients with acute viral hepatitis, immune hepatitis, Wilson disease, concurrent conditions in which free radical production is elevated like other inflammatory processes outside the liver or intake of antioxidant drugs affecting free radical scavenging such as vitamin $\mathrm{C}, \mathrm{A}$ and $\mathrm{E}$ at time of biopsy.

The selecting criteria for control group: children who had persistent or intermittent elevations in hepatic enzymes for more than 6 months and were found to have incidental "normal" liver biopsy. All cases were subjected to:

1) Full history taking including: personal history details, past and family histories; vaccination history.

2) Thorough clinical examination including: anthropometric measurements including height and weight, vital signs, general and local abdominal examination.

3) Routine laboratory investigations including: urine and stool analysis, complete blood count using Coulter counter, assessment of liver functions (total and direct bilirubin, ALT, AST, ALP and GGT; serum total proteins and albumin; prothrombin time and concentration).

4) Other laboratory investigations when needed e.g. $\mathrm{IGg}$.

5) Serological markers of $\mathrm{HBV}$ and $\mathrm{HCV}$ e.g. (HBsAg, $\mathrm{HBcAb}, \mathrm{HCVAb}, \mathrm{HCV}$ PCR).

6) Abdominal ultrasonography.

7) Glutathione peroxidase, superoxide dismutase and catalase levels in fresh liver tissue (cell free homogenates) using ELISA.

\subsection{Collection of Samples}

Liver tissue core was taken from each case using modified Minghini needle (sure cut). Each sample was divided into 3 portions, one for estimation of each enzyme and was stored at $-80^{\circ} \mathrm{C}$ till assay.

\subsection{Glutathione Peroxidase Assay}

Liver biopsy was washed in phosphate buffer, $\mathrm{pH}$ 7.4. Then, the tissue was homogenized in $5 \mathrm{ml} / \mathrm{gm}$ cold buffer, which consisted of $50 \mathrm{mM}$ tris- $\mathrm{HCl}, \mathrm{pH} 7.5,5 \mathrm{mM}$ EDTA, $1 \mathrm{nM}$ DTT. The homogenate was centrifuged at $10,000 \mathrm{xg}$ for $15 \mathrm{~min}$ at $4^{\circ} \mathrm{C}$. The supernatant was removed for assay of GPX. Glutathione peroxidase activity was measured using the Glutathione Peroxidase Assay Kit provided by Cayman Chemical Company, USA. Glutathione peroxidase catalyzes the reduction of hydroperoxides, including hydrogen peroxide, by reduced glutathione and functions to protect the cell from oxidative damage. With the exception of phospholipid hydroperoxide GPX, a monomer, all of the GPX enzymes are tetramers of four identical subunits. Each subunit contains a selenocysteine in the active site, which participates directly in the two-electron reduction of the peroxide substrate. The enzyme uses glutathione as the ultimateelectron donor to regenerate the reduced form of the selenocysteine. The Cayman Chemical Glutathione Peroxidase Assay Kit measures GPX activity indirectly by a coupled reaction with glutathione reductase (GR). Oxidized glutathione (GSSG) is produced upon reduction of hydroperoxide by GPX, and is recycled to its reduced state by GR and NADPH.The oxidation of NADPH to NADP + is accompanied by a decrease in absorbance at $340 \mathrm{~nm}$. Under conditions in which the GPX activity is rate limiting, the rate of decrease in the A340 is directly proportional to the GPX activity inthe sample $[10,11]$.

\subsection{Superoxide Dismutase Assay}

Liver biopsy was washed with $0.9 \% \mathrm{NaCl}$ to remove red blood cells. The tissue was then blotted dry and weighed followed by homogenization in $200 \mu \mathrm{l}$ buffer $(0.05 \mathrm{M}$ potassium phosphate and $0.1 \mathrm{mM}$ EDTA, $\mathrm{pH}$ 7.8) and centrifuged at $15,000 \mathrm{xg}$ for $30 \mathrm{~min}$ at $4^{\circ} \mathrm{C}$. The supernatant was used for determination of SOD.Superoxide dismutase was measured using the Superoxide Dismutase assay kit provided by Oxis research, USA SOD$525^{\mathrm{TM}}$. The BIOXYTECH assay is based on the SODmediated increase in the rate of autoxidation of 5, 6, 6a, 11b-tetrahydro-3, 9, 10-trihydroxybenzo[c]fluorene R1 in aqueous alkaline solution to yield a chromophore with maximum absorbance at $525 \mathrm{~nm}$. Interference due to mercaptans (RSH) such as reduced glutathione is controlled by pre-treating samples with 1-methyl-2-vinylpyridinium R2, which directly eliminates mercaptans by 
means of a fast alkylation reaction. The kinetic measurement of the $525 \mathrm{~nm}$ absorbance change is performed after the addition of R1. The SOD activity is determined from the ratio of the autoxidation rates in the presence (Vs) and in the absence (Vc) of SOD. The Vs/Vc ratio as a function of SOD activity is independent of the type of SOD (Cu/Zn-SOD, Mn-SOD, Fe-SOD) being measured $[10,11]$. One SOD-525 activity unit is defined as the activity that doubles the autoxidation rate of the control blank ( Vs/ Vc = 2).

\subsection{Catalase Assay}

Biopsy was washed with phosphate buffer, $\mathrm{pH} 7.4$, to remove red blood cells. The tissue was then blotted dry and weighed, followed by homogenization in $1.5 \mathrm{ml}$ cold buffer $(50 \mathrm{mM}$ potassium phosphate and $1 \mathrm{mM}$ EDTA $\mathrm{pH} 7$ ) and centrifugation at $10,000 \mathrm{xg}$ for $15 \mathrm{~min}$ at $4{ }^{\circ} \mathrm{C}$ was done. The supernatant was used for the assay.

Catalase assay kit provided by Cayman Chemical Company, USA. Catalase is a ubiquitous antioxidant enzyme that is present in most aerobic cells. Catalase (CAT) is involved in the detoxification of hydrogen peroxide $\left(\mathrm{H}_{2} \mathrm{O}_{2}\right)$. This enzyme catalyzes the conversion of two molecules of $\mathrm{H}_{2} \mathrm{O}_{2}$ to molecular oxygen and two molecules of water (catalytic activity). Catalase also demonstrates peroxidatic activity, in which low molecular weight alcohols can serve as electron donors, while the aliphatic alcohols serve as specific substrates. In humans, the highest levels of catalase are found in the liver, kidney, and erythrocytes, where it is believed to account for the majority of hydrogen peroxide decomposition. The Cayman Chemical Catalase Assay Kit utilizes the peroxidatic function of CAT for determination of enzyme activity. The method is based on the reaction of the enzyme with methanol in the presence of an optimal concentration of $\mathrm{H}_{2} \mathrm{O}_{2}$. The formaldehyde produced is measured spectrophotometrically with 4-amino-3-hydrazino5-mercapto-1,2,4-trizazole as the chromagen. The assay can be used to measure CAT activity in plasma, serum, erythrocyte lysates, tissue homogenates, and cell lysates $[10,11]$.

\subsection{Statistical Analysis}

SPSS for Windows, version 7.0 computer program was used for statistical analysis. A p-value of less than 0.05 was considered statistically significant. The t-test was used to compare between 2 independent means. Pearson Correlation coefficient (r) was used to measure the linear relationship between two quantitative variables. Data are represented as the mean \pm standard deviation.

\section{RESULTS}

Descriptive data of the children included in the study are represented in Table 1.

Mean levels of superoxide dismutase, glutathione peroxidase and catalase enzymes in the studied group are shown in Table 2. A significant difference $(p<0.05)$ was present in glutathione peroxidase mean levels between patients and controls. In Table 3, the three hepatic enzymes are further compared between each of the two chronic hepatitis subgroups and control children with no

Table 1. Descriptive data of studied children.

\begin{tabular}{|c|c|c|}
\hline Variable & $\begin{array}{l}\text { Hepatitis Group } \\
(\mathrm{n}=21)\end{array}$ & $\begin{array}{c}\text { Control Children } \\
(\mathrm{n}=7)\end{array}$ \\
\hline $\begin{array}{l}\text { Age (years) } \\
(\text { mean } \pm \text { S.D) }\end{array}$ & $8.1260+1.15$ & $3.62 \pm 3.17$ \\
\hline Sex (male/female) & $12 / 9$ & $3 / 4$ \\
\hline History of operation & $11(52.4 \%)$ & $0(0 \%)$ \\
\hline Physical signs & (no. $/ \%$ ) & (no. $/ \%)$ \\
\hline $\begin{array}{l}\text { Jaundice } \\
\text { Loc abdominal signs }\end{array}$ & $1(4.7 \%)$ & $0(0 \%)$ \\
\hline *Hepatomegaly & $4(19 \%)$ & $0(0 \%)$ \\
\hline *Splenomegaly & $5(23.8 \%)$ & $0(0 \%)$ \\
\hline *Ascites & $0(0 \%)$ & $0(0 \%)$ \\
\hline \multicolumn{3}{|l|}{$\begin{array}{l}\text { Hematological } \\
\text { Findings }(\text { mean } \pm \mathrm{SD})\end{array}$} \\
\hline$\bullet \mathrm{Hb}(\mathrm{gm} / \mathrm{dl})$ & $10.67 \pm 1.27$ & $10.74 \pm 1.26$ \\
\hline $\begin{array}{l}\text {-Platelets } \\
\left(\times 1000 / \mathrm{mm}^{3}\right)\end{array}$ & $332.65 \pm 126.9$ & $387.1 \pm 77.3$ \\
\hline $\begin{array}{l}\text {-WBCs } \\
\left(\times 1000 / \mathrm{mm}^{3}\right)\end{array}$ & $7.68 \pm 4.24$ & $7.59 \pm 2.51$ \\
\hline
\end{tabular}

Table 2. Comparison between mean levels $( \pm \mathrm{SD})$ of superoxide dismutase (SOD), glutathione peroxidase (GPX) and catalase (CAT) enzymes in the studied group and control children.

\begin{tabular}{cccc}
\hline Variable & $\begin{array}{c}\text { SOD } \\
(\mathrm{U} / \mathrm{mg} \text { Ptn })\end{array}$ & $\begin{array}{c}\text { GPX } \\
(\mathrm{nmol} / \mathrm{min} / \mathrm{ml})\end{array}$ & $\begin{array}{c}\text { CAT } \\
(\mathrm{nmol} / \mathrm{min} / \mathrm{ml})\end{array}$ \\
\hline $\begin{array}{c}\text { Patient Group } \\
(\mathrm{n}=21)\end{array}$ & $0.69 \pm 0.39$ & $38.59 \pm 35.82^{*}$ & $8.11 \pm 1.12$ \\
$\begin{array}{c}\text { Control Children } \\
(\mathrm{n}=7)\end{array}$ & $0.33 \pm 0.15$ & $10.62 \pm 6.68$ & $7.24 \pm 1.74$ \\
\hline
\end{tabular}

${ }^{*}=$ significant difference $(\mathrm{p}<0.05)$ between patient group and control children.

Table 3. Comparison between mean levels $( \pm \mathrm{SD})$ of superoxide dismutase (SOD), glutathione peroxidase (GPX) and catalase (CAT) enzymes in (chronic hepatitis) subgroups and control children.

\begin{tabular}{cccc}
\hline Variable & SOD $(\mathrm{U} / \mathrm{mg}$ Ptn $)$ & $\begin{array}{c}\text { GPX } \\
(\mathrm{nmol} / \mathrm{min} / \mathrm{ml})\end{array}$ & $\begin{array}{c}\text { CAT } \\
(\mathrm{nmol} / \mathrm{min} / \mathrm{ml})\end{array}$ \\
\hline $\begin{array}{c}\text { Viral hepatitis } \\
(\mathrm{n}=13)\end{array}$ & $0.67 \pm 0.47$ & $40.05 \pm 39.02$ & $8.00 \pm 1.21$ \\
$\begin{array}{c}\text { Hepatitis of } \\
\text { unknown }\end{array}$ & $0.72 \pm 0.26$ & $36.22 \pm 32.35$ & $8.27 \pm 1.02$ \\
$\begin{array}{c}\text { aetiology }(\mathrm{n}=8) \\
\text { Control children } \\
(\mathrm{n}=7)\end{array}$ & $0.33 \pm 0.15$ & $10.62 \pm 6.68$ & $7.24 \pm 1.74$ \\
\hline
\end{tabular}

No significant difference existed between mean levels of different enzymes in patient subgroups and control children. 
significant differences among them. Correlations between liver function tests and the three enzymes in the chronic hepatitis group are shown in Table 4. Studying the correlations among the two subgroups of our study revealed significant correlations between SOD level and ALT, AST and ALP in the viral hepatitis subgroup, whereas there was a significant correlation between SOD and DB in the second subgroup (hepatitis of unknown etiology). As regards GPX activity, a significant correlation existed between GPX and ALT in viral hepatitis subgroup and between GPX and PC in hepatitis of unknown etiology subgroup. There were no significant correlations between CAT activity and liver function tests in both subgroups.

\section{DISCUSSION}

Oxidative stress is a major pathogenetic event occurring in several liver disorders ranging from metabolic to proliferate ones, and is a major cause of liver damage in Ischemia/Reperfusion during liver transplantation. The main sources of ROI are mitochondria, cytochrome P450 enzymes in the hepatocyte, Kupffer cells and neutrophils [12].

HCV causes chronic hepatitis, which often results in liver cirrhosis and hepatocellular carcinoma [13]. HCV infection is associated with elevated levels of ROS in patients [14]. Chronic hepatitis C infection has been shown to cause mitochondrial GSH depletion [15]. HCV gene expression induced ROI, and inactivation of ROI led to a decrease in HCV replication. These results implicate a possible role for ROS in HCV RNA replication [13].

The present study showed a significant increase in the hepatic GPX activity in the group of children with chronic hepatitis whereas non-significant increase was observed in hepatic SOD and CAT activities as compared to the control group. Also a significant correlation was found between GPX and ALT level.

This significant increase in hepatic GPX in chronic hepatitis group is in harmony with Chrobot et al., (2000) who observed the significant increase in hepatic GPX in erythrocytes of children with chronic viral hepatitis $\mathrm{B}$ and $\mathrm{C}[2]$.

The oxidative stress is high in hepatitis patients, and there are significant correlations among HCV-RNA and erythrocyte MDA, erythrocyte GR and plasma GPX activities. Se-dependent GPX modules are encoded in a number of RNA viruses, including HIV-1, HCV, Coxsackie's virus B3, and HIV-2 virus. HCV-encoded GPX gene might demonstrate that oxidant stress is associated with HCV disease progression [16].

It has been suggested that enhanced oxidative stress in $\mathrm{HCV}$ infection may be attributed to the increased production of pro-inflammatory cytokines reported to occur in this condition. Activated neutrophils, macrophages and Kupffer cells have been reported to be basic sources of ROS in the course of the inflammatory process in the liver in children with chronic hepatitis C [17].

Oxidative stress may affect the efficiency of the effecttor mechanisms of the immune response [18], and it has also been shown to make cells more susceptible to apoptosis [19]. It is possible; therefore, that oxidative stress in lymphoid cells may impair the antiviral immune response, thus facilitating chronicity of HCV infection [1].

This significant increase in GPX can be attributed to GPX being an enzyme whose function is to protect erythrocyte membrane against oxidation by decomposition of $\mathrm{H}_{2} \mathrm{O}_{2}$ from other organic peroxides. Therefore, it regulates concentration of hydrogen peroxide in tissues that do not contain catalase or show its insufficient activity. In addition, elevated glutathione peroxidase activity may be explained on the basis of non-significant increase

Table 4. Correlation between liver function tests and SOD, GPX, CAT in chronic hepatitis group.

\begin{tabular}{|c|c|c|c|c|c|c|}
\hline & \multicolumn{2}{|c|}{ SOD (U/mg Ptn) } & \multicolumn{2}{|c|}{$\mathrm{GPX}(\mathrm{nmol} / \mathrm{min} / \mathrm{ml})$} & \multicolumn{2}{|c|}{$\mathrm{CAT}(\mathrm{nmol} / \mathrm{min} / \mathrm{ml})$} \\
\hline & r value & $\mathrm{p}$ value & r value & $\mathrm{p}$ value & r value & $\mathrm{p}$ value \\
\hline TB & 0.152 & $>0.05$ & -0.072 & $>0.05$ & 0.157 & $>0.05$ \\
\hline DB & 0.266 & $>0.05$ & -0.014 & $>0.05$ & 0.449 & $>0.05$ \\
\hline ALT & 0.369 & $>0.05$ & 0.486 & $<0.05^{*}$ & 0.179 & $>0.05$ \\
\hline AST & 0.227 & $>0.05$ & 0.273 & $>0.05$ & 0.075 & $>0.05$ \\
\hline ALB & 0.047 & $>0.05$ & 0.062 & $>0.05$ & 0.557 & $>0.05$ \\
\hline PT & 0.214 & $>0.05$ & -0.156 & $>0.05$ & 0.111 & $>0.05$ \\
\hline $\mathrm{PC}$ & 0.091 & $>0.05$ & 0.139 & $>0.05$ & 0.109 & $>0.05$ \\
\hline ALP & 0.359 & $>0.05$ & 0.269 & $>0.05$ & 0.209 & $>0.05$ \\
\hline GGT & 0.335 & $>0.05$ & 0.329 & $>0.05$ & -0.221 & $>0.05$ \\
\hline
\end{tabular}

*There is significant correlation between ALT level and GPX activity in chronic hepatitis cases. TB: total bilirubin; DB: direct bilirubin; ALT: alanine transaminases; AST: aspartate transaminases; ALB: albumin; PT: prothrombin time; PC: prothrombin concentration; ALP: alkaline phosphatase; GGT: gamma glutamyl transferase. 
of SOD and CAT in the present study. This is suggested to lead to the accumulation of superoxide and hydroxylic radicals in a cell. GPX might neutralize their toxic action and compensate in some way the loss of defense capability against oxygen radicals [2].

Interferon with or without ribavirin is the only drug with proven efficacy in treating chronic HCV infections [20]. Unfortunately, these therapeutic models maintain the rate of sustained virologic response to approximately $10 \%-40 \%$ [21]. On the basis of this evidence, antioxidants represent a logical therapeutic strategy for the treatment of chronic liver disease and the effective advancement in the antiviral treatments against chronic hepatitis $\mathrm{C}$ is necessary.

Complementary medications may be helpful in the treatment of hepatitis C. A combination of antiviral and anti-oxidative therapies may enhance the overall response rate of these patients. A combination of multiple antioxidants in patients with chronic HCV infection may ameliorate the inflammatory response as measured by liver enzymes and liver biopsy inflammatory score [22]. Vitamin E and selenium can also effectively decrease the degree of hepatic fibrosis and promote the recovery process [23].

In conclusion, the present study provides evidence that the hepatic disease may present without significant effect on blood oxidative status. Consequently, the best way is to measure hepatic oxidants and antioxidants in liver biopsy, which reflects the actual status of the liver. Understanding the redox regulation may have important clinical ramifications in understanding the pathogenesis of liver diseases and developing therapeutic approaches. These preliminary results are encouraging to conduct more extensive clinical studies combining antioxidant therapy with various treatments.

\section{ACKNOWLEDGEMENTS}

This work was supported by the grant from the National Research Centre, Cairo Egypt.

\section{REFERENCES}

[1] Boya, P., De la Pena, A., Beloqui, O., Larrea, E., Conchillo, M., Castelruiz, Y., Civeira, M.P. and Prieto, J. (1999) Antioxidant status and glutathione metabolism in peripheral blood mononuclear cells from patients with chronic hepatitis C. Journal of Hepatology, 31, 808-814. doi:10.1016/S0168-8278(99)80281-5

[2] Chrobot, M., Szaflarska-Szczepanik, A. and Drewa, G. (2000) Antioxidant defense in children with chronic viral hepatitis B and C. Medical Science Monitor, 6, 713-718.

[3] Cesaratto, L., Vascotto, C., Calligaris, S. and Tell, G. (2004) The importance of redox state in liver damage. Annals of Hepatology, 3, 86-92.
[4] Jabłonowska, E.H., Tchorzewski, H.P., Lewkowicz, P. and Kuydowicz, J.J. (2005) Reactive oxygen intermediates and serum antioxidative system in patients with chronic $\mathrm{C}$ hepatitis treated with IFN- $\alpha$ and thymus factor X. Archivum Immunologiae et Therapiae Experimentalis, 53, 529-533.

[5] Favier, A. (2006) Oxidative stress in human diseases. Annales Pharmaceutiques Françaises, 64, 390-396.

[6] Farinati, F.R., Cardin, R.N., De Maria, N., et al. (1995) Iron storage, lipid peroxidation and glutathione turnover in chronic anti-HCV positive hepatitis. Journal of Hepatology, 22, 449-456. doi:10.1016/0168-8278(95)80108-1

[7] Barbaro, G.G.D., Lorenzo, G.D.M., Ribersani, M., et al. (1999) Serum ferritin and hepatic glutathione concentrations in chronic hepatitis $\mathrm{C}$ patients related to the hepatitis $\mathrm{C}$ virus genotype. Journal of Hepatology, 30, 774-782. doi:10.1016/S0168-8278(99)80128-7

[8] Madan, K., Bhardwaj, P., Thareja, S., Siddhartha, D.G. and Saraya, A. (2006) Oxidant stress and antioxidant status among patients with nonalcoholic fatty liver disease (NAFLD). Journal of Clinical Gastroenterology, 40, 930935. doi:10.1097/01.mcg.0000212608.59090.08

[9] Czeczot, H.D., Scibior, D.M., Skrzycki, M. and Podsiad, M. (2006) Glutathione and GSH-dependent enzymes in patients with liver cirrhosis and hepatocellular carcinoma. Acta Biochimica Polonica, 53, 237-241. www.actabp.pl

[10] Ismail, N.A., Okasha, S.H., Dhawan, A., Abdel, A.M.O., Rahman, A.M.O., Shaker, O.G. and Sadik, N.A.H. (2009) Glutathione peroxidase, superoxide dismutase and catalase activities in hepatic tissue from children with glycolgen storage disease. Archives of Medical Science, 5, 8690 .

http://www.termedia.pl/Glutathione-peroxidase-superoxid e-dismutase-and-catalase-activities-in-hepatic-tissue-from -children-with-glycogen-storage-disease, 19,12292,1,1.ht $\underline{\mathrm{ml}}$

[11] Ismail, N.A., Okasha, S.H., Dhawan, A., Abdel Rahman, A.M.O., Shaker, O.G. and Sadik, N.A.H. (2010) Antioxidant enzyme activities in hepatic tissue from children with chronic cholestatic liver disease. Saudi Journal of Gastroenterology, 16, 90-94. doi:10.4103/1319-3767.61234

[12] Cesaratto, L., Vascotto, C., Calligaris, S. and Tell, G. (2004) The importance of redox state in liver damage. Annals of Hepatology, 3, 86-92.

[13] Waris, G., Turkson, J., Tarek Hassanein, T. and Siddiqui, A. (2005) Hepatitis C virus (HCV) constitutively activates STAT-3 via oxidative stress: role of STAT-3 in HCV replication. Journal of Virology, 79, 1569-1580. doi:10.1128/JVI.79.3.1569-1580.2005

[14] Swietek, K. and Juszczyk, J. (1997) Reduced glutathione concentration in erythrocytes of patients with acute and chronic viral hepatitis. Journal of Viral Hepatitis, 4, 139141.

[15] Han, D., Hanawa, N., Saberi, B. and Kaplowitz, N. (2006) Role of glutathione redox status in liver injury. American Journal of Physiology, Gastrointestinal and Liver Physiology, 291, 1-7. doi:10.1152/ajpgi.00001.2006

[16] Zhang, W., Ramanathan, C.S., Nadimpalli, R.G., Bhat, 
A.A., Cox, A.G. and Taylor, E.W. (1999) Selenium-dependent glutathione peroxidase modules encoded by RNA viruses. Biological Trace Element Research, 70, 97-116. doi:10.1007/BF02783852

[17] Wisniewska-Ligier, M., Wozniakowska-Gesicka, T., Lewkowicz, P., Kups, J. and Andrzejewski, A. (2004) Neutrophil oxidative metabolism in children with chronic hepatitis C. Przegl Lek, 61, 1338-1341.

[18] De-Haan, J.B., Wolvetang, E.J., Cristiano, F., Iannello, R., Bladier, C., Kelner, M., et al. (1997) Reactive oxygen species and their contribution to pathology in down syndrome. Advances in Pharmacology, 38, 379-402. doi:10.1016/S1054-3589(08)60992-8

[19] Buttke, T.M. and Sandstrom, P.A. (1994) Oxidative stress as a mediator of apoptosis. Immunology Today, 15, 7-10. doi:10.1016/0167-5699(94)90018-3

[20] McHutchison, J.G., Gordon, S.C., Schiff, E.R., Shiffman, M.L., Lee, W.M., Rustgi, V.K., Goodman, Z.D., Ling, M.H., Cort, S. and Albrecht, J.K. (1998) Interferon alfa-
$2 \mathrm{~b}$ alone or in combination with ribavirin as initial treatment for chronic hepatitis C. The New England Journal of Medicine, 339, 1485-1492. doi:10.1056/NEJM199811193392101

[21] Hoofnagle, J.H. (1999) Management of hepatitis C: Current and future perspectives. Journal of Hepatology, 31, 264-268. doi:10.1016/S0168-8278(99)80414-0

[22] Melhem, A., Stern, M., Shibolet, O., Israeli, E., Ackerman, Z., Pappo, O., Hemed, N., Rowe, M., Ohana, H., Zabrecky, G., Cohen, R. and Ilan, Y. (2005) Treatment of chronic hepatitis $C$ virus infection via antioxidants-Results of a phase I clinical trial. Journal of Clinical Gastroenterology, 39, 737-742. doi:10.1097/01.mcg.0000174023.73472.29

[23] Shen, X., Cheng, W., Li, X., Sun, J., Li, F., Ma, L. and Xie, L. (2005) Effects of dietary supplementation with vitamin $\mathrm{E}$ and selenium on rat hepatic stellate cell apoptosis. World Journal of Gastroenterology, 11, 4957-4961. 